\title{
Low Reproduction Success of Calliandra calothyrsus and It's Implication for Breeding
}

\author{
Liliana Baskorowati ${ }^{1, *}$ Rina Laksmi Hendrati ${ }^{1}$ Nur Hidayati ${ }^{1}$ Mashudi ${ }^{1}$ Mudji \\ Susanto $^{1}$ Dedi Setiadi ${ }^{1}$
}

\author{
${ }^{l}$ Forest Biology and Tree Improvement Research and Development Centre, Ministry of Environment and \\ Forestry, Jl Palagan T Pelajar km 15, Purwobinangun, Pakem, Sleman, Yogyakarta \\ *Corresponding author. Email: liliana.baskorowati@gmail.com
}

\begin{abstract}
In anticipating the rapid decrease of energy resource, especially fossil fuel, immediate actions are required to fulfil the needs of highly increased population in the world. Innovation to produce renewable energy from easily utilized raw materials should meet society's needs including renewable raw materials from wood biomass for energy. Genetically improved Calliandra calothyrsus has been developed for this purpose. Due to low success rate of its reproduction, study on its reproductive biology was undertaken. The study was carried out during the flowering seasons of $C$. calothyrsus, by examining flower morphology, pollen, and pistil viabilities as wee as insect visitors to this species' flowers. The study showed that the flowers of $C$. calothyrsus are borne on inflorescences (spikes) and carrying an average of 354 individual flowers, which develop acropetally. Pistils (female organ) cease to develop by the $2^{\text {nd }}$ to $3^{\text {rd }}$ day after their appearance, and the flowering is becoming ceased then. Pistils showed maturity during the period of $09.00 \mathrm{WIB}-10.00 \mathrm{WIB}$ and pollen is still viable from 1 to 3 days after the pollen opening. Three most frequent visitors (families: Apidae, Vespidae, Formicidae) and one order lepidoptera were found visiting $C$. calothyrsus flowers However, the reproductive success of $C$. calotyrsus is found to be very low, which is only 0.024 . These preliminary results confirmed that the low reproductive success of $C$. calothyrsus is due to the structure and development of flowers allowing the incidences of both outcrossing and self-pollination. The limitation time of pistil maturity might also contribute to the low reproductive success of this species.
\end{abstract}

Keywords: Calliandra calothyrsus, flowering, morphology, reproductive success

\section{INTRODUCTION}

Due to the depletion of fossil fuels for human needs, the use of renewable energy or biofuels is necessary. Innovation to produce renewable energy from easily utilized raw materials should meet society's needs including renewable raw materials from wood biomass for energy. Genetically improved of C. calothyrsus has been developed for this purpose. Red-flowered C. calothyrsus is a species that widely cultivated in Indonesia due to high biomass production. This species generally, grow well in areas with elevations $800 \mathrm{~m}$ above sea level, thus allowing optimization of land use in slope areas including on hill slopes. Planting this species is also able to improve the environment by resisting erosion and increasing soil fertility [1] This species has been planted in Indonesia as a source of fuelwood, pulp and paper, forage, honey, shellac and as an ornamental $[1,2]$. Therefore, planting superior seeds of $C$. calothyrsus will be very promising to meet industrial supply. C. calothyrsus is a forest plant with andromonecious or bisexual flower. The flower structure of $C$. calothyrsus is complete, consisting of an ovary, pistil, stylus, stigma, stamens or pollen that are sticky, crown, petals, and flower stalks in one individual flower [2,3]. Reproduction of $C$. calothyrsus is constrained due to the difficulty of fertilization especially during the pollination process. Anatomically and physiologically C. calothyrsus tends to have a low probability of success in the pollination process. The low reproductive success can be caused by several things; such as, the pistil structure is much higher than the stamens, the pollen 
viability degrades quickly, the effective time of pollination is very short, visitors and specific pollinators rarely land on flowers, the receptivity period of the pistil and pollen, pollen sterility and flower freshness that only last for short periods $[4,5]$.

Detailed knowledge of flowering time and flowering phenology is very important to determine reproductive success. According to [6] reproductive success can be clearly identified when information is available such as time of bud's formation, time of flowering, time of fertilization, season, duration and intensity of flowering. Research on flowering plays a very important role in the population dynamics of a species, because successful of pollination can be done by increasing or delaying flowering $[7,8]$. Furthermore, [9] stated that knowledge of the morphology of flowering will determine the mating pattern of a species, and this is very important in determining strategies to manage a population to produce good seeds. In addition, knowledge of insect pollinators or visitors to a species is very important to understand in order to determine its reproductive success [10].

So far, research on the flowering morphology of C. calothyrsus species in Indonesia has not been widely carried out. Although information about flowering already exists, information about the constraints of reproductive success of this type is still very limited. Therefore, this study was conducted with the aim of (1) Determining the morphology of C. calothyrsus flowering; (2). Determining the stages and intensity of flowering and fruiting of $C$. calothyrsus; and (3). Determine the reproductive system by calculating the reproductive success of $C$. calothyrsus.

\section{MATERIALS AND METHODS}

The research was conducted in the $C$. calothyrsus clone test plot at the Forest Biology and Tree Improvement Research and Development Centre, in Februari - November 2018. Data collection used the following methods:

\subsection{Flower development}

Observation of flowering and fruiting time and the intensity of $C$. calothyrsus inflorescences was carried out by counting the number of inflorescences (not individual flowers) and young fruit on all trees contained in the test plot. Flowering observations are carried out by counting the number of inflorescences in each individual. Observation the development of the generative organs, especially the appearance of signs of flowering (bud formation), the formation of flowers and development into fruit; done every day. Observation of the length of time that the sexual organ development lasts start from the flower initiation stage, when the reproductive shoots appear macroscopically until the fruit and seeds are ripe. Generative organ observation was carried out on 3 trees with abundant flowers.

\subsection{Flower Visitors}

Observation of pollinator was carried out at the peak of flowering in several trees with abundant flowers. Observations were undertaken in the morning at 08.00 ; in the afternoon at 16.00 , for 5 minutes each for five consecutive days. Observation at night time, was undertaken by using yellow insect traps installing at different heights close to the flowers. The number of insects visiting flowers and made contact with the flowers was recorded and counted, while insect samples were collected by catch using a net for further identification. Observations of nectar production were carried out in the morning at 08.00 and noon at 12.00 , using microhematocrit. The nectar is then taken to the Biochemistry and Food Chemistry laboratory at the Faculty of Agricultural Technology UGM for sugar content analyses.

\subsection{Reproductive Success}

Observations of the mating system were carried out by conducting an experiment to calculate the reproduction success by comparing natural pollination and self-pollination. Observations were made on 3 trees with abundant flowers. In each sample tree, the twig with inflorescences is labeled with the date of commencement of the observation, then the number of flower buds is calculated. For natural pollination experiments, inflorescences were left open, while for self-pollination experiments were carried out by covering inflorescences containing flowers that were ready to bloom with a pollination bag [11]. Two weeks after treatment, the pollination bag was opened, and the number of fertilized flowers was counted. The calculation of reproductive success is done by comparing the number of flowers before blooming with the number of fruits formed.

\section{RESULTS AND DISCUSSIONS}

\subsection{Flower development}

C. calothyrsus flowers grow terminally or grow on the tip of a branch (Figure 1) arranged in one panicle (inflorescences). C. calothyrsus flowers consisting of 
female and male organs in one flower (hermaphrodite), which has a pistil as a female organ and stamens (consisting of anthers) as a male organ in one flower (Figure 1). One inflorescence, consisting of several pinnacles bearing numbers of different flowers (mean $26.06 \pm 1.92$ flower buds). The development of buds into anthesis (time flower's open) is not synchronous in one panicle, with a tendency to follow acropetal flower

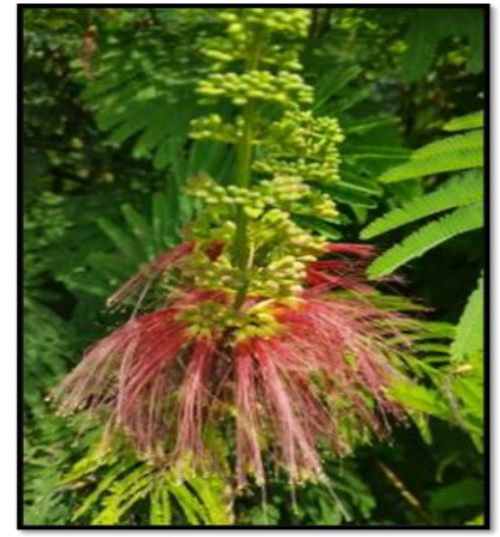

development, i.e., the flowers ripen from the bottom to the top. This type of flower morphology allows a great chance for autogamy which will reduce the viability of seeds due to a decrease in the good character of a population. Flower buds will experience an increase in size from when they start to look macroscopic until they reach their maximum size at anthesis (see Table 1).



Figure 1. Reproductive organs of Calliandra Callotyrsus

C. calothyrsus flowers are also heterostyly (Figure 1), which the size of the pistil is longer than the stamen (pin) or vice versa (trump). As presented in Table 1, it can be seen that the mean pistil length was $8.14 \pm 0.15 \mathrm{~mm}$; while the mean length of stamens was $6.11 \pm 0.16 \mathrm{~mm}$. According to $[12,13]$, heterostyly is a form of polymorphism in plants, especially in flowers. In heterostyly, there are two or three different types of flower morphology in a plant population. The difference in flower morphology, among others, lies in the difference in the length of the stamens and pistils. This apparent phenotype trait is genetically linked to the genes responsible for the self-incompatibility system. In this selfincompatibility system, pollen from one flower cannot pollinate other flowers with the same morphology [14]. The difference in the length of stamens and pistils in flowers is heterostyly adapted to the occurrence of pollination by different pollinating agents. The pollen derived from the long stamen (trump type) will pollinate the long pistil (pin type) [15]. If the movement of stamens between two flowers occurs in the same morphological type, fertilization will not occur because of the selfincompatibility mechanism. From the observations, most of the $C$. calothyrsus has a heterostyly-pin type, so the possibility of interbreeding in one tree is very small.

Thus,

pollen transfer really needs a pollinator to get heterostylytrump type flowers so that marriage compatibility can occur.

In general, the development of generative organs is a series of stages starting from (1) the flower induction stage; (2) the stage of flower initiation or pre-anthesis; (3) the flowering or anthesis stage; (4) pollination and fertilization stages; (5) the stage of fruit development towards maturity [16]. The results of observations on the development of the generative organs of $C$. calothyrsus are as follows:

1. Flower Induction. Flower induction is the first stage of the flowering process in which the vegetative meristem is cellularly transformed into a generative meristem, or a transitional change from juvenile to adult $[7,16]$. Macroscopically, these changes are generally characterized by various characteristics such as changes in leaf shape; increased thickness of leaf shoots, increased production of branches and twigs, formation of plagiotropic branches; or shortening internodia [17]. The C. calothyrsus species, the most obvious flower induction is the reduction in leaf size and shorter internodia. The interest induction can be found from June to August. 
Table 1. The measurements of flowers and organ reproductive of C. calothyrsus

\begin{tabular}{lcc}
\hline \multicolumn{1}{c}{ Measurements } & Average & Se \\
\hline Number of buds in an inflorescence & 354 buds & 31.27 \\
Number of buds in a panicle & 26.1 buds & 1.90 \\
Number of panicles in an inflorescence & 16.30 pinnacles & 0.60 \\
Length of an inflorescences & $10.82 \mathrm{~cm}$ & 0.61 \\
Diameter of buds (a week after formed) & $2.56 \mathrm{~mm}$ & 0.45 \\
Number of stamens & $32.76 \mathrm{stamens}$ & 0.71 \\
Length of stamens (the first day of anthesis) & $6.11 \mathrm{~mm}$ & 0.16 \\
Length of pistils (the first day of anthesis) & $8.14 \mathrm{~mm}$ & 0.15 \\
\hline
\end{tabular}

\section{Note $\mathrm{Se}=$ Standard error}

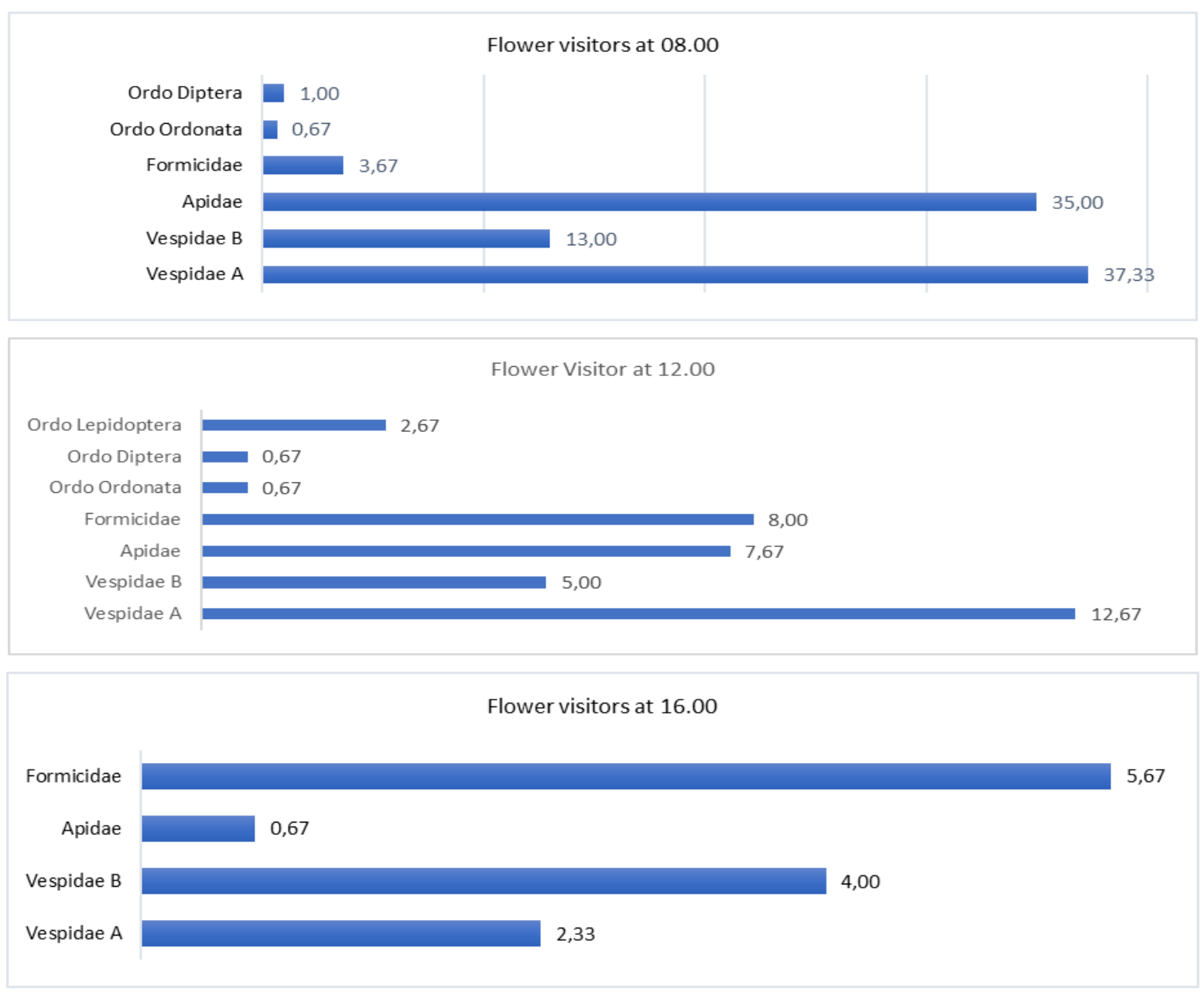

Figure 2. Mean of flower visitors of C.calotyrsus during 3 time observations

(2) Flower initiation stage (pre-anthesis). Flower initiation is the first morphological appearance of reproductive shoots that can be seen macroscopically, which can be detected from changes in the shape and size of buds, as well as the subsequent processes that start to form reproductive organs [17]. C. calothyrsus flower initiation is indicated by the appearance of a flowering bud on each end of the petiole. There is swelling of the shoots (differentiation) starting from the base of the shoots and finally forming compound flower buds with flower bud stalks (Figure 2a). For approximately 30 days, the size of the flower 
buds will swell so that they reach their maximum size on the 30-32th day. A bud with optimal swelling is characterized by opening of the petal followed by the appearance of stamens as shown in Figure 2b.

(3) Anthesis, which is the stage when the flowers - the flower crowns and their reproductive organs open completely. Generally, it is a sign that the reproductive organs have reached maturity, although in some types of reproductive organs maturity occurs before the flowers bloom or after the flowers bloom. $C$. calothyrsus, anthesis is characterized by the maximum flower crown; followed by the erection of the pistil and stamens (Figure 3). The timing of Calliandra's anthesis is believed to have occurred at night or very early in the morning; because all the flowers reached the peak of the buds swelling at afternoon then, the following morning has opened.

(4) Pollination and fertilization stage. Pollination or transfer of pollen (male organs) to the pistil (female organs) occurs when the two reproductive organs have reached receptivity. The pistil releases a clear liquid as a place for pollen to attach as a sign of maturity of the female organs, while the pollen pouch will break and release pollen as a sign of maturity of the male organs. [7] states that pollination is the first stage in the reproductive process and is followed by fertilization if pollination is successful. C. calothyrsus has a relatively short pollination time, characterized by pollen receptivity which only occurs on the first day after anthesis. On the second day after anthesis, the anthers and pistils wilt indicating post-receptivity.

(5) The stage of fruit development towards maturity. This stage begins with enlargement of the ovaries (ovaries), followed by the development of food reserves (endosperm), and subsequent embryonic development. In Calliandra, the development of flower buds, flowers and fruit until the fruit reaches maturity takes 6-7 months. C. calothyrsus fruit is green when young and will turn brown in color as the seeds ripen. Calliandra fruit is pod-shaped, flat, with the number of seeds in it that varies between $2-8$ seeds.

\subsection{Flower visitor}

The observation of insect visiting flowers of $\mathrm{C}$. calothyrsus showed a variety of insect visitors. The numbers of insect visiting flowers varies between time of observation and within time of observations. In this observation, insects were identified at the ordo level, however we found that ordo Vespidae had 2 types of insect A and B. Figure 2 illustrates the variety of insect visiting flowers of Calliandra, it shows that Vespidae comprised the majority of insects recorded visit the flowers following by Apidae, Formicidae and Vespidae B.

Chamberlain, 1994 reported many different insects and animal visit the flowers of C. calotyrsus, including bee, wasp, bats, birds, butterfly and moths; however, only bats and moths will actually pollinate the Calliandra flowers. Meanwhile, HernándezConrique, Ornelas, García-Franco, \& Vargas, (2007) reported that Calliandra longipedicellata flowers are visited mainly by large moths and bats, and diurnally by several species of bees, bumblebees, wasps.

In non-wind-pollinated species, flowers are visited by a variety of pollen vectors; however, the vector capability to remove and deposit pollen varies accordingly $[19,20]$. The feeding behavior and size of insect visitors, for example, influence the effectiveness of transferring pollen to stigma [18]. Ineffective pollinators may reduce reproductive success, due to clogging the stigma with incompatible pollen [21]. [22] stated that pollinator



Figure 3. Mean of nectar production of Calliandra calothyrsus

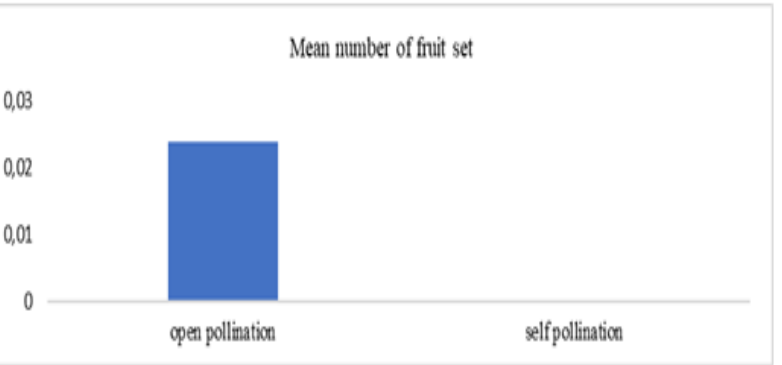

Figure 4. Mean number of fruit set following open and self-pollination of Calliandra calotyrsus 
effectiveness depends on their ability to transfer pollen between stigmas, flowers and trees, and the frequency with which pollinators visit individual flowers.

\subsection{Reproductive Success}

In this study, the reproductive success of $C$. calotyrsus were found to be very low, which is only 0.024 . This observation also found that the average number of flowers observed were 354 and only 7,7 fruits set following open pollination treatment, whereas no fruit were set following self-pollination treatment (Figure 4). The observation shows that this species is preferentially out crossing; however, the percentage of fruit set under open pollination is very low.

\section{CONCLUSION}

Flower of C. calothyursus is hermaphrodite, arranged in inflorescences bearing $26.06 \pm 1.92$ flower buds. The flowers develop acropetally, with bottom commencing of anthesis first follows by upper buds. Therefore, the flowering time were not synchronous within and between inflorescences. C. calothyrsus flowers are also heterostyly, which the size of the pistil is longer than the stamen (pin) or vice versa (trump). Flowering development begins with the flower induction stage which occurs 1-2 months before buds are formed. Flower buds develop in inflorescences of approximately 30 days until the first buds open. Flowers generally open at night, or early morning and will be withered or post anthesis the next morning.

The stigma and pollen receptivity are only momentary, causing a low pollination process naturally in this species. Flower bud development to fertilization and ripe fruit takes 6-7 months. The pollination system in this type is indicated by crosspollination, this is evidenced by the experimentation itself which did not produce any results at all. The reproductive success of this species is also very low, only 0.024 percent of flowers can become fruit with open pollination treatments. This result may concordance with the flower visitors which may only come to flowers without any contact with the anthers that contain the pollen. The insects just visit the bottom of the flower and collect the nectar; which means they do not pick-up pollen and transfer pollen to other flowers. Therefore, the lack of insect's visits flowers also due to the structure and development of flowers allowing the incidences of both outcrossing and self-pollination which may contribute to the low reproductive success of this species.

\section{ACKNOWLEDGMENT}

The author would like to thank Andra Salsabila, Amarilis Kesuma and Rijal Romolo (Gadjah Mada University undergraduate students) for their assistance in observing and collecting data in the field. Thanks to Forest Biotechnology and Tree Improvement Research Development Center for their support during this study.

\section{REFERENCES}

[1] R. Hendrati, Suwandi, Margiyanti, Budidaya Kaliandra (Calliandra calothyrsus) untuk Bahan Baku Sumber Energi. Nai'em M, Mahfudz, Prabawa S, editor. IPB Press, 2014. [In Bahasa Indonesia]

[2] H.M. Hernandez, Taxonomy, geographical distribution, and reproductive biology of Calliandra calothyrsus (Leguminosae, Mimosoideae) a species of agroforestry potential. Anales - Instituto de Biologia, Universidad Nacional Autonoma de Mexico, Serie Botanica, 62(2) (1991) 121-132.

[3] R. Greissl, Ontogeny of the Calliandra massulae (Mimosaceae: Ingeae), and the associated viscin body. Flora - Morphology, Distribution, Functional Ecology of Plants, 201(7) (2017) 570-87. DOI: https://doi.org/10.1016/j.flora.2005.11.002.

[4] L. Baskorowati, M.W. Moncur, J.D. Doran, P.J. Kanowski, Reproductive biology of Melaleuca alternifolia (Myrtaceae) 1. Floral biology. Australian Journal of Botany 58(5) (2010) 37383. DOI: https://doi.org/10.1071/BT10035.

[5] S. Dewi, A. Rahayu, N. Rochman, Morfologi Bunga dan Viabilitas Serubk Sari Sebagai Aksesi Pamelo (Citrus maxima (Burm.) Merr.). Jurnal Agronida 1(1) (2015) 38-42. DOI: http://dx.doi.org/10.30997/jag.v1i1.130. [In Bahasa Indonesia]

[6] L. Baskorowati, J.D. Doran, M. Moncur, Reproductive Biology of Melaleuca alternifolia (Maiden \& Betche) Cheel and The Implications for breeding system. Germany: LAP Lambert Academic Publishing House, 2010.

[7] M. Sedgley, A.R. Griffin, Sexual Reproduction of Tree Crops, 1989. 
[8] A.R. Griffin, P.P. Cotterill, Genetic variation in growth of outcrossed, selfed and open-pollinated progenies of Eucalyptus regnans and some implications for breeding strategy. SilvaeGenetica 37 (1988) 124-31.

[9] A. Morgan, S.M. Carthew, M. Sedgley, Breeding system, reproductive efficiency and weed potential of Acacia baileyana. Australian Journal of Botany 50 (3) (2002) 357-64. DOI: https://doi.org/10.1071/BT09116.

[10] W.A. Haber, G.W. Frankie, Pollination of Luehea (Tiliaceae) in Costa Rican deciduous forest. Ecology. 1982.

[11] L. Baskorowati, Controlled pollination methods for Melaleuca alternifolia (Maiden \& Betche) Cheel. ACIAR Technical report, 2006.

[12] S.C.H. Barret, The evolution of mating strategies in flowering plants. Trends in Plant Science 3(9) (1998) 335-41.

[13] S.C.H. Barrett, J. Hough, Sexual dimorphism in flowering plants. Vol. 64, Journal of Experimental Botany (2012) 67-82. DOI: https://doi.org/10.1093/jxb/ers308

[14] L. Baskorowati, Depresi Silang Dalam Biji dan Semai Melaleuca alternifolia. Jurnal Pemuliaan Tanaman Hutan 11(2) (2017) 87-98. DOI: https://doi.org/10.20886/jpth.2017.11.2.87-98.

[In Bahasa Indonesia]

[15] L. Baskorowati, S. Pudjiono, Morfologi Pembungaan dan Sistem Reproduksi Merbau (Intsia Bijuga) pada Plot Populasi Perbanyakan di Gunungkidul. Jurnal Pemuliaan Tanaman Hutan 9(3) (2015) 161-78. DOI: https://doi.org/10.20886/jpth.2015.9.3.159-175. [In Bahasa Indonesia]
[16] H. Hartmann, D. Kester, F. Davies, R. Geneve, Plant propagation: Principles and practices. Biochemical Systematics and Ecology, 2010.

[17] M. Sedgley M, J. Harbard, R.M.M. Smith, R. Wickneswari, A.R. Griffin, Reproductivebiology and interspecific hybridization of acacia-mangium and acacia-auriculiformis cunn,a ex benth (leguminosae, mimosoideae). Australian Journal of Botany 40(1) (1992) 3748. DOI: http://dx.doi.org/10.1071/BT9920037.

[18] D, Hernández-Conrique, J.F. Ornelas, J.G. García-Franco, C.F. Vargas, Nectar production of Calliandra longipedicellata (Fabaceae: Mimosoideae), an endemic Mexican shrub with multiple potential pollinators. Biotropica 39(4) (2007) 459-467. DOI: https://doi.org/10.1111/j.17447429.2007.00277.x.

[19] H.G. Baker, K. Faegri, L. van der Pijl L, The Principles of Pollination Ecology. The Journal of Ecology. 1972.

[20] S. Armbruster, C. Fenster, M. Dudash, Pollination "principles" revisited: specialization, pollination syndromes, and the evolution of flowers. The Scandanavian Association for Pollination Ecology. 39 (2000) 179-200.

[21] N.M. Waser, L. Chittka, M.V. Price, N.M. Williams, J. Ollerton, Generalization in pollination systems, and why it matters. Ecology 77(4) (1996) 1043-60. DOI: https://doi.org/10.2307/2265575.

[22] R.B. Primack, Relationships among flowers, fruits, and seeds. Annual review of ecology and systematics 18 (1987) 409-430. DOI: https://doi.org/10.1146/annurev.es.18.110187.00 $\underline{2205}$. 